\title{
R.J. de Weijs* \\ Secured credit and partial priority: \\ Corporate finance as a creation or an externalisation practice?
}

https://doi.org/10.1515/eplj-2018-0004

\begin{abstract}
Four developments warrant revisiting the debate on full priority and taking steps to implement a partial priority system. The first development is that secured credit increasingly results in a complete lack of funds to cover the expenses of the insolvency procedure. The second development is that secured credit is often not doing what the proponents of full priority argue that it is doing, namely facilitating growth. Instead, it is increasingly used to simply facilitate the leverage of the company without any intent to invest in the company. Thirdly, the plight of unsecured creditor is deteriorating in new ways. Trade creditors in particular are increasingly forced into the position of being suppliers of credit, turning non-adjusting creditors into what can be referred to as adjustable creditors. The fourth development is that these trade creditors find insolvency laws increasingly working against them instead of for them.
\end{abstract}

\section{Introduction}

Secured credit at its best allows for investment in wealth creating projects. It allows companies to invest and to grow. Not only does the company, its shareholders and the secured creditor benefit, but also suppliers and employees, as well as the general public through taxation. From this perspective, secured credit can be defended as 'the oil of the economy', which fosters investments. While one can lament that the effect of security rights on insolvency proceedings is often that other creditors receive close to nothing, this cannot be the only measure of the effect of security rights. ${ }^{1}$ Reducing the rights of secured creditors will not only affect the outcome in a given insolvency case, but will also affect lending beha-

1 See also Mooney and Harris 1994, p. 2036.

*Corresponding author: Prof. Dr. R.J. de Weijs, University of Amsterdam, E-Mail: r.j.deweijs@uva.nl

Ә Open Access. (c) 2018 R.J. de Weijs, published by De Gruyter. (c) BY-NC-ND This work is licensed under the Creative Commons Attribution-NonCommercial-NoDerivatives 4.0 License. 
viour and reduce the availability of credit, which in turn might hamper investment.

Although there is ample criticism of the strong position of secured creditors, this usually does not translate into a plea for abolition, but rather a plea for partial priority. While under full priority the secured lender is paid in full out of encumbered assets before any money flows to the estate and other creditors, under partial priority a secured creditor will be unsecured in part and will have to render a percentage of the proceeds to the estate.

The argument that will be developed in this article is that four major and consistent developments warrant revisiting the debate on full priority and taking steps to implement a partial priority system. The first development is that secured credit increasingly has as a consequence that there are no funds to cover the expenses of the insolvency procedure. The second development is that secured credit is less and less doing what the proponents of full priority argue that it is doing, namely facilitating growth. Instead, it is increasingly used to simply facilitate the leverage of the company without any intend to invest in the company. Thirdly, the plight of unsecured creditor is deteriorating in new ways. Trade creditors in particular are increasingly forced into the position of being suppliers of credit, turning non-adjusting creditors into what can be referred to as adjustable creditors. The fourth development is that these trade creditors find insolvency laws increasingly working against them instead of for them, adding insult to injury.

The structure of this article is as follows. First the dynamics of leveraged finance will be set out in $\S 2$, which also discusses the deterioration of the position of trade creditors. This is followed by revisiting the full versus partial priority debate in $\S 3$, which also fleshes out the arguments made in favour of full priority. Subsequently, in $\S 4$, a distinction will be made between productive credit and non-productive credit. Since secured finance is heavily involved in providing non-productive credit, while securing this at the expense of non-adjusting creditors, the balance should be recalibrated. $\S 5$ discusses how partial priority would protect creditors and would lead to a more robust financial climate which is more in line with basic free market oriented capitalism. 


\section{The role of secured credit as part of leveraged finance}

\subsection{General effects of leverage}

Although most like to stay well away from incurring too much debt, and a potential situation of insolvency, there is a global tendency for companies to do just the opposite: to take on as much debt as possible. The total amount of debt in the non-financial sector has more than doubled since $2000 .^{2}$ One of the reasons for taking on debt is that the shareholders can increase their return on the equity invested (Return on Equity or ROE) by having the company taking on debt. This is referred to as leveraged finance. In the case of leveraged finance, the company is being financed with little shareholder money but significant money from creditors in the form of debt. The more debt the company takes on, the higher the leverage of that company.

The easiest way to understand leveraged finance, is to see its effects by using an example and a balance sheet. ${ }^{3}$ A company, with a balance sheet total of $€ 1000$, which is initially financed solely by one shareholder's money is therefore financed $100 \%$ by equity. Now assume that the company has made a profit of $€ 80$. In order to establish whether $€ 80$ is a lot, one needs to take into account how much money the shareholder has put into the company in order to earn said $€ 80$. In the case at hand, the shareholder invested $€ 1000$. The ROE is therefore $8 \%$. On each euro invested, the shareholder has made 8 cents.

2 See on the aggregate debt levels IMF Fiscal Monitor 2016, p. 1. The global gross debt of the nonfinancial sector has more than doubled in nominal terms since the turn of the century, reaching \$ 152 trillion in 2015. The current debt level is at an all time high and has reached the level of 225 percent of the world GDP.

3 The method used here of balance sheets depicting the relative shares of finance by means of blocks has been developed by Joost de Vries, JBR Institute as part of the Financial Mind Map@). 


\section{Balance without leverage}

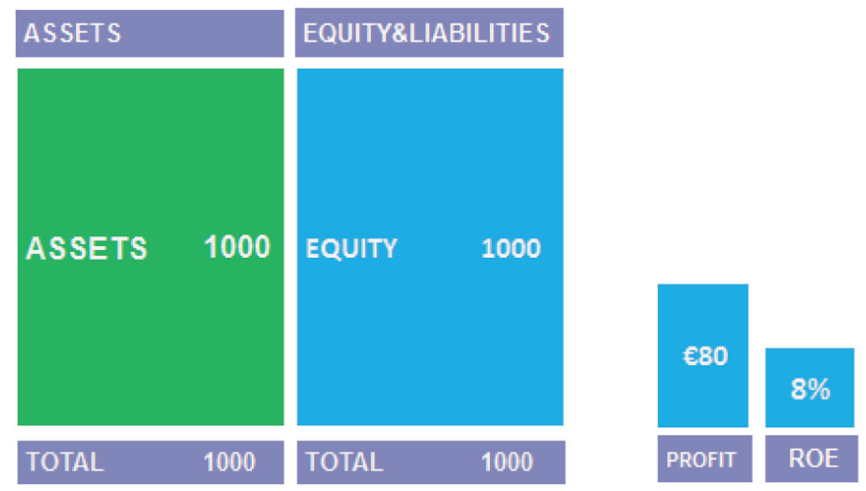

Leveraged finance is a way to increase returns for shareholders, not through cutting costs or attracting more customers, but by increasing the leverage of the company. The profit before interest ${ }^{4}$ in all subsequent examples will remain at a set level of $€ 80$.

What if the company is no longer financed solely by equity, but has also taken on debt? What if the company has borrowed €350 from a bank? On the right side of the balance sheet, the debt to the bank appears as a liability. The company is now no longer solely financed by shareholders but also by creditors. The company will now have to start paying interest to the bank of, e.g., $4 \%$ annually. Therefore it will have to pay $€ 14$ to the bank. Of the $€ 80$ in profit, $€ 14$ needs to be paid to the bank. The remaining profit for the shareholder is reduced to $€ 66$. The shareholder has, however, personally invested less. Now the shareholder has only invested $€ 650$. This means that with an investment of $€ 650$, the shareholder has now made $€ 66$. This equals an ROE of $10.2 \%$, so one can already see a small increase of the ROE from $8 \%$ to $10.2 \%$.

4 If a corporate income tax rate of $20 \%$ would be introduced, and assuming no depreciations and amortization, the EBITDA would be at a set level of 100. Taxes will not be included in the examples themselves. 


\section{Leveraged finance (I)}

\section{ASSETS}

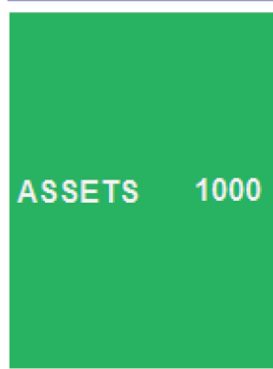

TOTAL

\section{EQUITY\&LIABILITIES}

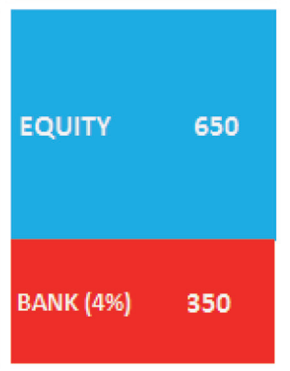

TOTAL

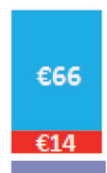

PROFIT

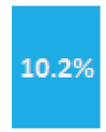

ROE

The same dynamics present themselves if the company takes on more debt and thereby increases its leverage. Another source of financing by means of debt is attracting financing from suppliers. An unpaid supplier is a creditor of the company until they are paid. Typically, a company is financed by equity and different type of creditors. In the case at hand, there could be outstanding invoices from suppliers for a total of $€ 550$. At the level of $€ 900$ as the total amount of outstanding debt, again against an interest rate of $4 \%$, the ROE increases to $44 \%$.

\section{Leveraged finance (II)}

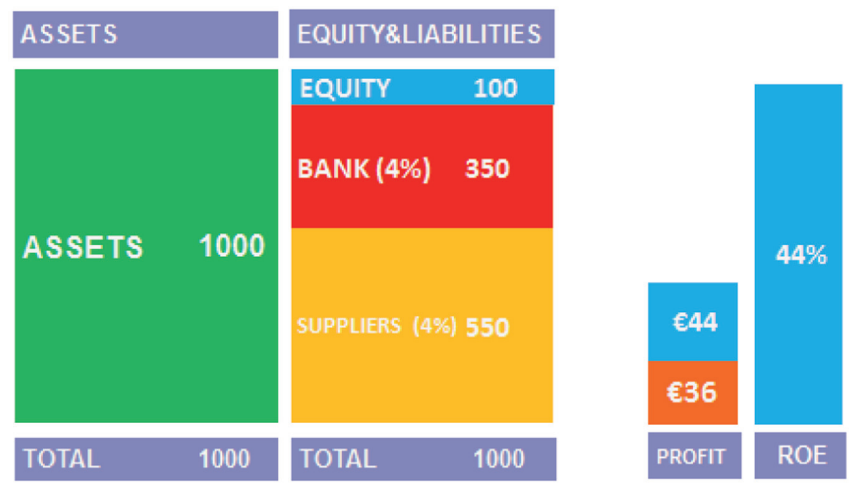


The increased ROE is one of the great attractions of leveraged finance. The total amount of profit available after interests is of course reduced, in this instance from the initial $€ 80$ to the $€ 44$ in the last figure. Leveraged finance is on the whole not attractive for shareholders, if the shareholder would take out funds from the company and place those at a savings account providing 1\% interest annually. Leveraged finance is however most attractive if one can use the equity spared to invest it elsewhere against similarly high returns, for example, in another leveraged company or a portfolio of companies.

Secured credit plays a pivotal role in creating leveraged structures in at least two ways. First of all, in order to create significant leverage, professional creditors will want to limit their potential risk. This is most commonly done through security rights. Secondly, because of the reduced risks resulting from secured credit, the secured creditors will normally lower their interest rates, thereby creating a stronger positive effect for the shareholders from the leveraged structure itself.

\subsection{Corporate Finance Theory}

The increasing ROE in relation to increased leverage seems quite spectacular at first sight. This raises the question whether value is created by leverage itself, and if so, who benefits. Corporate finance theory is preoccupied with the question of whether there is an ideal mix of debt and equity finance. The founding theory of corporate finance has been developed by Modigliani and Miller. They hold that there is no magic in leveraged finance and that no value is created by increasing the leverage itself, neither for the company, nor for the shareholders. ${ }^{5}$

There are several assumptions underlying the Modigliani and Miller theorem that leverage does not matter and does not create value for the company or its shareholders. The conditions ${ }^{6}$ under which the theorem would hold are the existence of perfect markets ${ }^{7}$ with complete information ${ }^{8}$ to which both indivi-

5 The first proposition of Modigliani and Miller is that the value of a firm is independent of its capital structure. See Miller 1988, p. 99: "Our proposition I, holding the value of a firm to be independent of its capital structure (that is, its debt/equity ratio) is accepted as an implication of equilibrium in perfect capital markets." See this first proposition in more complex wordings, Modigliani and Miller 1958, p. 268, 269.

6 See on the conditions in general, Fama 1978.

7 See Modigliani and Miller 1958, p. 268.

8 See Miller 1988, p. 105: “... one of the key assumptions of both the leverage and dividend models, namely that all capital market participants, inside managers and outside investors alike, have the same information about the firm's cash flows." 
duals and companies have equal access, ${ }^{9}$ the ability to properly price ones risk, ${ }^{10}$ no bankruptcy costs ${ }^{11}$ and no taxes. ${ }^{12}$

One of the main ideas underlying Modigliani and Miller's theory is that if the firm takes on more debt, the firm becomes riskier for the creditors. In the examples above, the insolvency risk has not been included in the analyses of different ROE depending on the leverage of the company. Increasing leverage does increase the risk profile of the company itself, since there is less of an equity cushion to absorb losses and since the costs of debt increase. If the company does enter into insolvency procedures, the available assets will need to be shared by a larger pool of creditors. Adjusting creditors with full information will price in their risk and raise the interest charged in relation to increased leverage. ${ }^{13}$ So, under perfect market conditions, an attempt to increase the return for shareholders by increasing leverage would be compensated by creditors adjusting the price of their credit. Any resulting increase in the ROE for shareholders would also be offset by a greater risk for the shareholders. Not only does the company become a more risky endeavour for its creditors, but also for its shareholders. ${ }^{14}$ The increased risk for the shareholders under the assumptions made by Modigliani and Miller would match their increased return exactly. Here one can see the great attraction of the Modigliani and Miller theorem itself, and how it can be both used and misused by warding off criticism against any high yield gained by shareholders. In a perfect world, high returns for shareholders are a compensation for higher risks and nothing more than that.

\section{See Fama 1978, p. 273.}

10 See Meyers 2001, p. 85: “Any attempt to substitute "cheap" debt for "expensive” equity fails to reduce the overall cost of capital because it makes the remaining equity still more expensive - just enough more expensive to keep the overall cost of capital constant." In the words of Miller 1988, p. 100: "Proposition II, which showed that when Proposition I held, the cost of equity capital was a linear function of the debt/equity ratio. Any gains from using more of what might seem to be cheaper debt capital would thus be offset by the correspondingly higher cost of the now riskier equity capital." See this second proposition in more complex wordings, Modigliani and Miller 1958, p. 271.

11 Fama 1978, p. 273 lists 'no bankruptcy costs' as an element of perfect markets.

12 See on the absence of taxes, Modigliani and Miller, 1958, p. 273.

13 See for this notion of adjusting creditors explicitly Brealy, Meyers and Allen 2006, p. 455 : "Increasing the amount of debt increased debtholder risk and led to a rise in the return that debtholders required." The focus in Modigiliani and Miller in 1958 was excessively on the shareholder, and implicitly more or less assumed risk free bondholder debt. See apologetic as to not really including the riskiness of credit, Miller 1988, p. 107, 108.

14 In the examples above only the outcome in a positive going concern scenario have been discussed. In order to calculate the expected return ex ante, one would also have to determine the bankruptcy risk and determine how much each party would receive then. 
In order to understand the central notion of Modigliani and Miller, one has to understand that ultimately both shareholders and creditors receive cash generated by the company. No specific division of these future cash flows can increase the available cash flows themselves. One can use the metaphor of a pizza. Slicing a pizza into smaller or larger slices does not increase the amount of pizza on offer. $^{15}$

In the real world, finance obviously does matter, and in light of a global trend towards financialisation, increasingly so. Miller himself believed that the value of the theorem was not only to be found in its abstract claims that capital structures do not matter in perfect markets meeting all the assumptions, but also when used the other way around. By identifying why capital structure and leverage matter, one can identify imperfections or exceptions to the assumptions that do exist. ${ }^{16}$

The most important take away from the Modigliani and Miller theorem is the notion that leveraged finance itself does not create value in the sense that there is some kind of extra surplus to be divided among all stakeholders. To the extent that leveraged finance does create value for the shareholders, one should look for externalities. Externalities can be defined as 'any welfare effect felt by one party as a result of another actor's production or consumption decisions that is not mediated via the price system'. ${ }^{17}$ If there is no more pizza coming out of the company, but the shareholders do increase their expected returns, this must come from some other stakeholder. Since the capital structure ${ }^{18}$ only consists of equity and debt, a creditor must end up paying for the increased expected returns for the shareholders.

Below, two clear and basically undisputed exceptions will be discussed regarding why finance does matter. Two prominent settings will be discussed where the increase in ROE as a result of increased leverage is stronger than any increase in risk for the shareholders: the first being 'interest-free debt' and the second being taxes.

15 See Meyers 2001, p. 85.

16 See Miller 1988, p. 100: “Showing what doesn't matter can also show, by implication, what does."

17 Armour 2000, p.363.

18 It is also possible to externalize financial risks to parties outside of the capital structure, as is the case of Too Big To Fail. The analysis here is limited to changing the capital structures. If the governance changes as well, benefits might be gained thereof. See for the disciplining effect of debt and possible indirect yet significant side effects, $§ 4$ below. 


\subsection{Seeing why finance does matter: Interest free debt, from non adjusting to adjustable creditors}

Modigliani and Miller assumed perfect markets. They showed that no wealth was created by leverage itself. They did not dwell long on the position of creditors, especially not the extent to which risks were being externalized. Modiglini and Miller assumed perfect markets with full information where all parties can adequately price their risks. In a follow-up article, Miller recognised that if creditors are not compensated for increased risks related to increased leverage, value is taken from these creditors and transferred to shareholders. He wrote the following in 1988:

"Even in a no-tax world the "no gain from leverage" implication of the original MM invariance proposition might fail if the new debt was not made junior in status to the old, if the old bond covenant was "open ended," as many still are, and if the new bonds were issued under it. Assuming no change in the underlying earning power from the recapitalization, the original creditors would then find the value of their claim diluted. The benefits of this dilution of the old bondholders accrue, of course, to the stockholders, which is why it has often been labelled 'theft', particularly by the adversely affected bondholders. Finance specialists prefer the less emotionally charged term "uncompensated wealth transfer."

In the examples given above, it has been assumed that all creditors were entitled to $4 \%$ interest annually. If the conditions of Modigliani and Miller were to be applied, creditors would increase the interest charged in step with the increase in leverage in order to reflect the increase in their risk of bankruptcy. ${ }^{19}$ The unsecured creditors would also factor in their higher risk, by demanding a higher interest on their outstanding claim. In as far as creditors do not increase the price of their credit by increasing their interest rates if the company takes on more debt, shareholders benefit at the expense of these creditors, euphemistically referred to as an 'uncompensated wealth transfer'.

In practice, however, exactly the opposite is happening. Financing a company intentionally with non-interest bearing debt has developed into a standard finance strategy, commonly deployed by private equity investors. There are two distinct steps within this strategy. The first step is increasing the payment terms to unsecured creditors, typically suppliers. The second step is to not pay any interest at all after increasing the share of supplier finance. A striking example

19 Modigliani and Miller originally did not include bankruptcy risks. A later study by Stiglitz 1969 includes bankruptcy and bankruptcy is now included in a standard analyses of Modigliani and Miller, with however the assumption that bankruptcy itself does not impose any costs, such as liquidator fees. 
can be found in the case of Douwe Egberts, a tea and coffee company. After Douwe Egberts had been acquired by a private equity fund, it extended its payments to its suppliers from 60 to 200 days, without interest compensation. ${ }^{20}$ Retail chains systematically extend the payment terms to unsecured suppliers, without any interest being paid.

If suppliers and other creditors have financed the larger part of the balance sheet and if they do not receive any interest, the ROE for shareholders increases significantly. If the last balance sheet above is taken and the suppliers would not receive interest on their outstanding claims, the ROE would increase further from the previous $44 \%$ to $66 \%$. $^{21}$ This is due to the fact that $4 \%$ interest no longer needs to be paid for $€ 900$ (being €36 in interest), but now only for €350 (i.e., €14 in interest).

\section{Leveraged finance with partial interest free}

debt
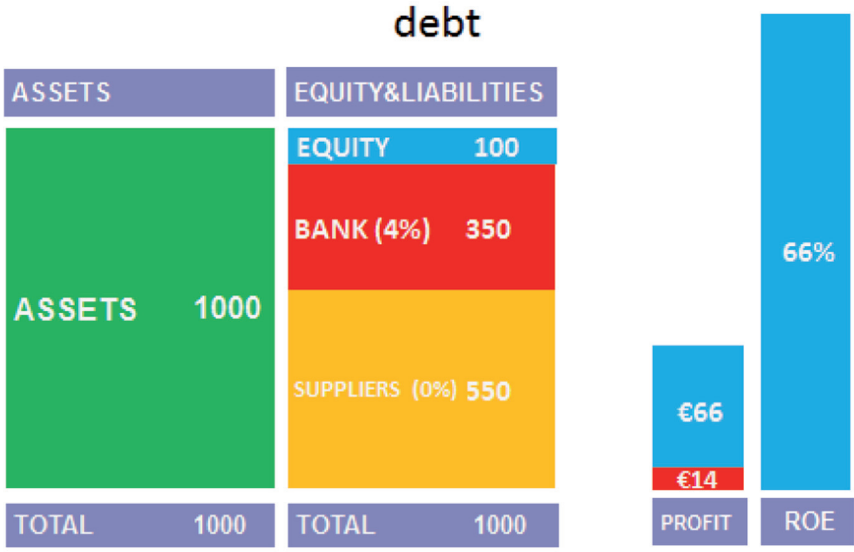

European rules are already in place to address this through the Directive on Combating Late Payment in Commercial Transactions. ${ }^{22}$ The Directive seeks to

20 See Business Insider 2013.

21 The bank would still receive an interest payment of €14 annually. The other creditors would not receive interest. Out of the total profit of $€ 80$, now $€ 66$ would remain for the shareholder. Under this scenario, the equity provided is however reduced to $€ 100$, resulting in an ROE of $66 \%$. 22 Directive 2011/7 of the European Parliament and of the Council of 16 February 2011 on Combating Late Payment in Commercial Transactions (Recast). In the Netherlands, additional rules have been implemented in art. 6:119a BW. These rules are effective as of July 1, 2017 and will apply to old contracts as of July 2018. These new strict rules apply to defined large companies 
limit companies who intentionally finance their company by demanding de facto financing from their suppliers. The basic rule is that Member States should ensure that in commercial transactions, payments should be made within 60 days. The same power dynamics which allow strong parties to force their suppliers into accepting longer terms in the first place, also prevent individual suppliers from bringing cases to courts. ${ }^{23}$

The problem of financing with non-interest bearing debt has not only led to a legislative response, but also to a societal response. In the Netherlands, with help of the Ministry of Economic Affairs, the 'Pay Me Now' initiative has been launched. The purpose of the initiative as presented is that companies should pay their suppliers and other creditors within a reasonable time period. ${ }^{24}$

buying from SME suppliers. The new rules basically provide for a penalty becoming due if the payment term is in excess of 60 days. In such a case, the high statutory interest (currently approximately $8 \%$ ) becomes due for the period in excess of 30 days. Theoretically, this would turn cheap suppliers' credit into expensive suppliers' credit. It will remain to be seen how effective these measures will be, also since the previous rules implementing the Late Payment Directive seemed to have had little effect. However, even if the companies buying goods do not change their payment behaviour immediately or would simply not pay the high interest, they will have difficult discussions with their accountant. Since the high statutory interest payment does become due, regardless of whether it is actually paid, it will somehow have to be accounted for in the annual accounts.

23 See Hausemer et al. 2015, p. 2.

24 See https://www.betaalme.nu/paymenow/. The English version, however, reveals that the initiative is partly turned into a supply chain finance tool. The initiative is not only supported by the Ministry but also by major banks offering supply chain finance. The effect first of all is that it further weakens the position of suppliers. Where suppliers might argue that the situation cannot be supported any longer, because suppliers also needs to pre-finance all deliveries themselves and do not have the funds to do so, buyers can now point to banks joining the initiative. Of course the banks will not pre-finance the invoices or accounts receivable for free. The end result being that the supplier ends up paying, for example, 5\% annually over its outstanding accounts receivable, while suppliers do not receive any interest on their invoices. Although one would expect the initiative Pay Me Now to address the problem of late payments head on, it seems to facilitate it. The site (at 17 July 2017) mentions the copyright being with (C) 2017 Supply Chain Finance Community. The site provides (again at 17 July 2017). 'Betaalme.nu seeks to unlock $€ 2.5$ billion in liquidity for Dutch SMEs in the next five years. It aims to do this by mobilising $50 \%$ of the top 1,000 corporates to offer their suppliers the opportunity of faster payment, or fast financing, of their invoices. Participating corporations draw up a pledge detailing the concrete steps they will take to ensure their smaller suppliers are paid more quickly for the products or services they supply. Corporations can contribute by approving their SME suppliers' invoices more quickly, then paying them faster or offering the option of fast and favorable financing by third parties.' (emphasis added). 


\subsection{Seeing why finance does matter: tax shield}

The second reason why finance does matter and creates wealth for shareholders is in the effect of the tax shield. The tax shield is a result of the general rule that interest payments are seen as a cost which is tax-deductible, whereas dividend payments are not tax-deductible.

The problem of taxation providing a further incentive to finance by means of debt instead of equity, is also on the European legislative agenda. In the 'Action Plan on Building a Capital Markets Union', the problem is identified as follows:

'Differences in the tax treatment of various financial instruments may impede efficient capital market financing. The preferential tax treatment of debt, resulting from the deductibility of interest rate payments, is at the expense of other financial instruments, in particular equity. Addressing this tax bias would encourage more equity investments and create a stronger equity base in companies. Also, there are obvious benefits in terms of financial stability, as companies with a stronger capital base would be less vulnerable to shocks. ${ }^{25}$

This tax benefit is now being reduced by the new European tax measures adopted in the Directive Laying Down Rules Against Tax Avoidance, ${ }^{26}$ which will be effective from January 2019 onwards. One of the core provisions of the directive is $\S 4$, which provides that interest is only tax deductible for the first $30 \%$ of the taxpayer's earnings before interest, tax, depreciation and amortisation (EBITDA).

The attractiveness of leveraged finance can be broken down into several elements, all adding to an increased ROE. The new measure contained in the Directive Laying Down Rules Against Tax Avoidance by no means results in an equal tax treatment of debt and capital finance, thereby leaving in place the fact that tax measures amplify the incentives already there to finance by means of debt rather than equity.

25 See EC Communication 2015/468 of 30 September 2015, Action Plan on Building a Capital Markets Union.

26 See Directive (EU) 2016/1664 of July 2016, Directive Laying Down Rules Against Tax Avoidance Practices that Directly Affect the Functioning of the Internal Market. 


\section{Debate on secured credit and its scope: the puzzle and partial priority}

\section{1. (Dis)solving the puzzle}

Secured debt has long been held to present a puzzle. The puzzle has mainly been formulated by Schwartz, following Modigliani and Miller. Where Modigliani and Miller held that there is no value to be created by opting for a specific mix of debt and equity finance, Schwartz takes the next step and argues that no value can be created by choosing between secured and unsecured debt as specific layers within the capital structure. Schwartz adds the element of costs. Since security rights cost money to create, and do not add value, the question arises why security rights are created. In the words of Schwartz:

"I made a series of assumptions much like those of MM and proved that firms cannot increase their value by issuing one form of debt rather than another. If they cannot, security should not be seen because security is costly for firms to issue; firms will not incur costs that are unmatched by corresponding gains. The logic of my proof also was simple. Secured creditors will charge lower interest rates because security reduces their risks, but unsecured creditors will raise their interest rates in response because security reduces the assets on which they can levy, and so increases their risks. The interest rate reductions are precisely matched by interest rate increases; hence, the firm makes no net gain from granting security." ${ }^{27}$

Schwartz is left with the puzzle of secured credit, since security rights cost money, without creating wealth for the shareholders. This is far less puzzling if one accepts that at least three assumptions of Modigliani and Miller are not met. The puzzle is then not so much solved as dissolved.

The first assumption that is not being met in practice is the assumption of perfect markets where parties adjust their prices according to risk. Where Schwartz assumes that unsecured creditors by and large raise their interest rates to precisely match their increased risk, this is normally not the case. He discusses some marginal examples of non-adjusting customers and employees. ${ }^{28}$ Little of the puzzle remains, if one introduces a significant amount of noninterest bearing debt into the balance sheet as is increasingly the case with

27 See Schwartz 1984, p 1054.

28 See Schwartz 1981, p. 30, 31 on what he refers to as an 'offensive distributional explanation' where firms issue secured debt in case they have creditors that do not adjust their price. 
trade creditors. Any non-compensated increase in risk on their part, translates itself into an uncompensated wealth transfer from these creditors to shareholders. The creditors are manoeuvred into a position where they cannot adjust their prices according to the package of security rights. It can then only be expected that the company will exploit this by attracting secured credit. The shareholders benefit from the increase in leverage, since the affected creditors do not adjust their prices.

The second assumption that is not being met, concerns a more theoretical issue, but one that is highly relevant as it goes directly to the heart of the Modigliani and Miller theorem and the discussion of secured credit. One of the more elusive assumptions underlying Modigliani and Miller's theorem is that the company and its shareholder can borrow at the same rate. A result from this assumption is that if value could be created by taking on debt (thus creating more leverage), there is no reason to do so at the level of the company. The investor could also do so by personally borrowing money in order to buy shares in the company. The leverage is then not created at the level of the company, but rather at the investor level. In perfect markets, where companies could borrow at the same rate as their investors, there is no reason why the company would create the leverage for the investors. ${ }^{29}$ This line of reasoning is usually referred to as 'home-made leverage'. This argument, elusive as it may be, is one of the founding assumptions of Modigliani and Miller. ${ }^{30}$ While Schwartz mentions the argument of home-made leverage, ${ }^{31}$ he does not link this specifically to the issue of secured credit. This is strange, since the whole issue of secured credit is extremely difficult to reconcile with Modigliani and Miller in as far as the assumption goes that the company and its shareholder could borrow under the same conditions. Where the company can grant a security right on its assets, the investor of course cannot grant a security right on the assets of the company. Even a pledge on the shares in the company held by the investors is not half as good as a pledge on the assets of the firm. This is another reason

29 Modigliani and Miller, 1958, p. 270: "We conclude therefore that levered companies cannot command a premium over unlevered companies because investors have the opportunity of putting the equivalent leverage into their portfolio directly by borrowing on personal account."

30 See Modigliani and Miller 1958 and see again Miller 1988 on both the argument and the place it takes as foundation for the MM theorem, p. 102: "Unlevered corporate equity streams could in turn be relevered by borrowing on individual account if unlevered streams ever sold at a discount relative to levered corporate equity. That possibility of "homemade leverage" by individual investors provided the second and completing blade of our arbitrage proof of value invariance."

31 See Schwartz 1984, p. 1053. 
why the puzzle is no longer a puzzle. A company will be able to borrow at a cheaper rate than the investor. If the company creates the leverage, it can do so on much better terms than the investor

The third assumption that is not being met is that there are no taxes. Schwartz of course recognises that this assumption is not met, ${ }^{32}$ but does not seem to attach much weight to it. ${ }^{33}$ The existence of taxes and their related tax shield alone already provides sufficient incentives to borrow money against security and incur the related costs.

\subsection{Partial priority in response to non-adjusting creditors}

Schwartz' analysis is a legal follow-up to Modigliani and Miller. Schwartz, however, did not advocate repealing the preferred position of secured debt on the basis of the puzzle identified, but rather that further research be conducted. In the 1990s US scholars Bebchuk and Fried provided a new impulse to the debate on secured credit by offering a detailed alternative to the favourable treatment of secured credit, by proposing partial priority. ${ }^{34}$ Partial priority means that in case of insolvency, the secured creditor does not take full priority over unsecured creditors, but some of the value of the encumbered assets flows to the unsecured creditors, leaving the secured creditor partly unsecured.

The working of partial priority can be shown by a balance sheet. The assumption will be that the bank has a valid security right in all assets. A company is balance sheet insolvent, if the value of the assets is less than the amount of outstanding debt. In the balance sheet, the two sides are then made equal by working with negative equity.

32 See Schwartz 1984, p. 1053.

33 See Schwartz 1984, p.1066, 1067

34 They took inspiration from German legislative proposals to that extent. See most notably the article by Drukarnczyck 1991. 


\section{Balance sheet insolvent}

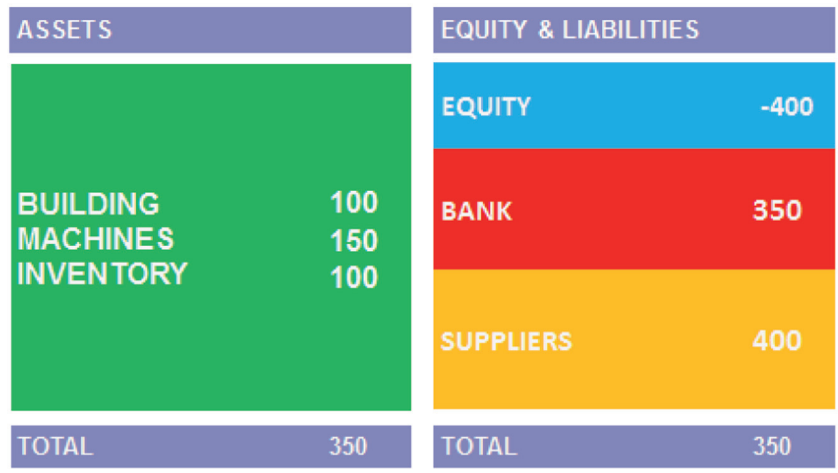

In the case of insolvency, the value in the company is no longer there for the benefit of the shareholders, but for the creditors. ${ }^{35}$ This can be visualised by placing the value of the assets at the level of the creditors.

\section{Balance sheet insolvent allocation of value with full priority}

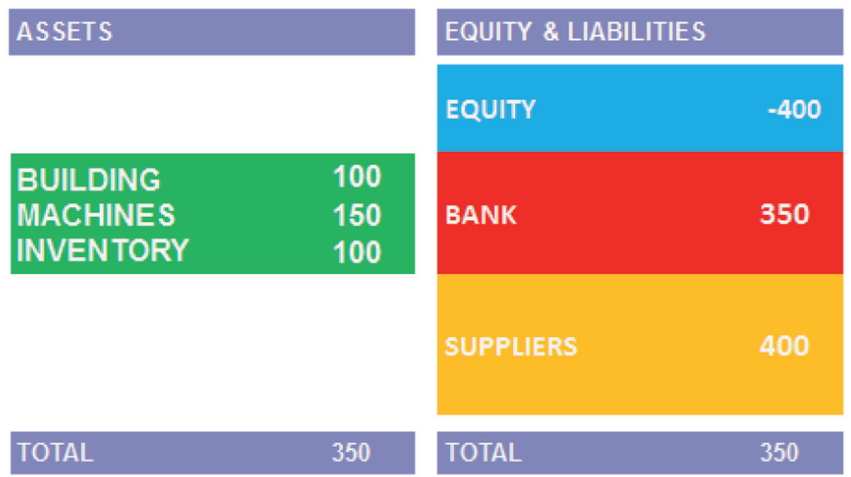

35 See Armour et al. 2017, p. 109. 
In the case at hand and ignoring liquidation costs, if the liquidation value would amount to $€ 350$, the bank would be paid $100 \%$, leaving nothing for the other unsecured creditors.

In the case of partial priority, some value will still flow to the unsecured creditors or at least to the estate, and leave the bank unsecured in part.

\section{Balance sheet insolvent allocation of value with partial priority}

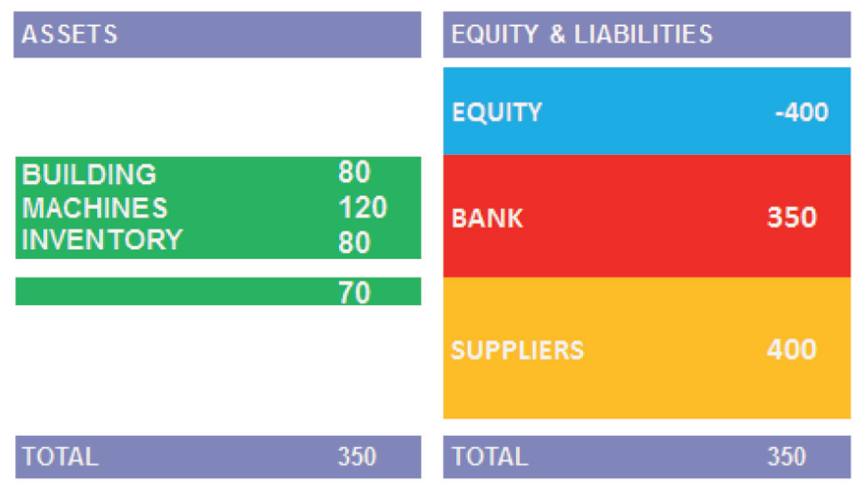

Different systems of partial priority have been proposed. The easiest is a carve-out system. Under a carve-out, a certain percentage, e.g., $20 \%$ of the proceeds of the encumbered assets does not flow to the secured creditor, but instead to the estate. ${ }^{36}$ This does not mean that the secured lender will necessarily become unsecured in part, since the secured creditor can limit its lending so it will not be impacted by the carve-out. One could therefore hold that such a rule does not necessarily lead to partial priority.

Fried and Bebchuk introduced three systems of partial priority, most prominently the fixed fraction priority rule. ${ }^{37}$ The fixed fraction priority system resembles the carve-out rule but is different in several aspects. The most important feature is that it ensures that the secured creditor is always unsecured to a certain extent. Under the carve-out system, the secured lender could reduce its available

36 See for a much debated carve-out proposal in the US of $20 \%$, Warren, 1996-1997.

37 See Fried and Bebchuk 1997, p. 1323, 1324. They also developed two other systems, being the Adjustable Priority Rule and the Consensual Priority Rule. See Fried and Bebchuk 1997, p. 13251327. 
credit in order to ensure that its claim remains fully secured. If the carve-out is $20 \%$, the secured lender under the carve-out system could limit the available credit to 80 if the asset, e.g., the office building is worth 100. For this reason, under the fixed fraction priority rule, the secured creditor will always be unsecured to a certain extent. If the lender would reduce its lending to 80 , it would then only be secured for $80 \%$ of the said 80 . Therefore the secured lender, having a claim of 80 against security worth 100, would have a secured claim of only 64 and an unsecured claim for 16. Fried and Bebchuk clarify the distinction by pointing out that a carve-out rule applies to collateral, while the partial-priority rule applies to claims. ${ }^{38}$ For this reason, they also do not consider a carve-out system to qualify as partial priority as presented by them. In $\S 5$ below, while discussing the beneficial effects of partial priority and the different goals that can be pursued, it will be discussed whether a rule of true partial priority needs to be used, or whether a more straight forward carve-out rule would suffice.

Fried and Bebchuk did not frame their proposals in the very abstract propositions of Modigliani and Miller, but were much more concerned by inefficiencies that can result from secured credit. They argued that the fact that security interests may be used to transfer value from non-adjusting creditors under a fullpriority rule means that security interests may be used even when they give rise to inefficiencies. ${ }^{39}$

\subsection{Praise for secured credit and full priority}

The increased academic critique of priority, or at least full priority, has led to several responses defending priority. The main arguments justifying full priority have been the following: freedom of contract, freedom of property and most importantly, that secured credit can be seen as the oil of the economy which fosters growth.

The first two arguments may be appealing as a form of legal basis, but upon closer inspection, the normative force of the arguments is weak at best. The argument in favour of freedom of contract provides that absent clear reasons, the

38 See Fried and Bebchuk 1997, p. 1347, 1348.

39 They discuss at great length five inefficiencies which are likely to follow from full priority (Bebchuk and Fried 1991, p. 895-903). They put forth the argument that the rule of providing full priority to secured claims may i) cause the use of inefficient security interests, ii) distort the choice between the use of security interests and covenants in loan contracts, iii) distort a firms' investment and precaution decisions, iv) lead to a suboptimal use of covenants and iv) reduce the incentive of secured creditors to appropriately control their borrowers' behaviour. 
law should not interfere with what parties agree upon. A strong counter-argument to this is that freedom of contract does not encompass the right to contract to the detriment of third parties, especially if contracting parties know that this third party has no way to respond. ${ }^{40}$ Allowing parties to contract that one creditor is allowed to take a step forward in the ranking has the same effect of agreeing with this creditor that all other creditors are given a lower rank. Whereas subordination requires the consent of the subordinated creditor, this is not the case when granting a security right. ${ }^{41}$

The basic argument relating to freedom of property argues that where the debtor has the power to transfer the ownership of the goods, the debtor should also have the power to perform less drastic acts, such as the encumbrance by a security right. ${ }^{42}$ Harris and Mooney in particular have argued that the justification for security rights should be found in the freedom of property..$^{43}$ In response, it should be noted that although a party is free to dispose of its assets, does not mean that the party is necessarily equally free to keep using the assets while at the same time allocating the value to one creditor in case of insolvency. ${ }^{44}$ The conceptual flaw in the analysis by Harris and Mooney becomes much clearer, if the corporate form with limited liability is introduced. The freedom of a company to dispose of its property does not mean that the company should also have the freedom to keep using the property to generate income for the shareholders, while at the same time attracting credit from a bank which can then be used to make dividend payments to shareholders reducing their risks.

Although Harris and Mooney base their argument in favour of full priority on a property right basis, in their rebuttal of arguments against full priority they present a much stronger argument in favour of secured credit and full priority. ${ }^{45}$

40 See McCormack 2004, p. 13: "Parties are free to barter away their own rights but are not free to give away the rights of those who did not consent to such treatment."

41 See Fried and Bebchuck, 1997.

42 See Harris and Mooney 1994, p. 2024: “The well-accepted rights of property owners - to use and freely and effectively to alienate their property and be secure in their ownership - form the basis of our normative theory of secured transactions."

43 See Harris and Mooney 1994, p. 2037-2041.

44 See McCormack 2004, p. 145: "The property-rights justification for security rights could also be attacked on the basis that the bankruptcy estate belongs to the borrowers' creditors as a group rather than to the borrower."

45 Armour gives a full overview of the law and economics debate, in Armour, 1998. He comes to the conclusion that of the theories advanced to explain the use of secured credit, the most plausible is that it functions to assist creditors in monitoring debtor behavior, and in bonding debtors to not misbehave. These are valid explanations for the use of security rights as well. However, these functions are also well preserved under partial. 
They argue that secured credit can be said to be the 'oil of the economy and the engine of economic growth'. ${ }^{46}$ Similar arguments in favour of secured credit are given by S.L. Schwarcz (not the puzzle Schwartz introduced above). He singles out new credit leading to an increase in liquidity and subsequent increase in assets as 'an easy case for secured credit'. ${ }^{47}$ The Uncitral Legislative Guide on Secured Transaction also presents the growth of businesses as the prime justification for security rights. ${ }^{48}$

According to Harris and Mooney, efficiency oriented scholars voicing criticism against full priority do not sufficiently take into account that security rights are not granted to simply secure old existing debts, but are created to attract new finance, leading to an increase in the pool of assets, ${ }^{49}$ allowing for credit that would otherwise not be extended. Even more dismissive of theoretical academic articles criticising secured credit is Kripke, the drafter of the old article 9 UCC in the US:

"These articles proceed in a world of academic reasoning reminiscent of the cloister and unfounded on any discussion of the factual world of commerce. They do not display any understanding of the role played by the system of secured financial credit in developing a distribution system for the great outpouring of goods that has occurred in the past century". ${ }^{50}$

46 See in these words McCormack 2004, p. 15.

47 Schwarcz 1997 defends secured credit and full priority, putting forth the example that secured credit will benefit both the company and its non-secured creditors, basically since the credit will be used to make investments in the company or at least provide liquidity to facilitate the running of the business. At p. 430 Schwarcz writes: "New money secured credit, which is the "easy" case referred to in this Article's title, must be distinguished from situations where the debtor grants security for existing debt. In the latter case, "the granting of security reduces the assets on which the remaining unsecured creditors can levy and thereby increases the risk for such unsecured creditors." New money secured credit, in contrast, does not necessarily reduce the assets on which unsecured creditors can levy because the debtor receives the loan proceeds. More importantly, the availability of new money secured credit reduces the risk that the debtor will go bankrupt by increasing a debtor's liquidity, and therefore increases the expected value of unsecured claims." As will be seen below in $\S 4$, the example Schwarcz has in mind is increasingly at odds with the actual use of secured credit, where it is increasingly used to facilitate leverage. In such cases of using secured credit to simply increase the leverage of the company without making investment or providing new liquidity, the expected value of unsecured claims will decrease instead of increase.

48 See Legislative Guide Uncitral 2010, p. 2: 'The Guide is based on the premise that sound secured transactions laws can have significant economic benefits for States that adopt them, including attracting credit from domestic and foreign lenders and other credit providers, promoting the development and growth of domestic businesses (in particular small and medium-sized enterprises) and generally increasing trade.'

49 See Harris and Mooney 1994, p. 2028. 
Finding the ultimate justification for secured credit in its function as the oil of the economy also provides a better perspective on for whose benefit security rights are ultimately facilitated by the law. Although security rights are typically granted to banks, the justification for allowing secured interest is not in the end to serve the interests of banks. Secured credit is a service facilitated by law, which the company can use for the benefit of its shareholders. In turn, it is assumed that allowing companies to invest and grow for the benefit of the shareholders will also benefit society at large. It is also up to the shareholders to decide whether the company wants to grow, how it will finance this growth strategy and whether it will finance the company with equity or debt. Maybe the company could also attract new finance as new outside equity. In that case, the shareholders would see their equity share diluted. To the extent that the company has assets or at least generates steady a income stream from debtors, it can provide security rights and attract debt finance and thereby grow without diluting the shareholders' position.

One can see security rights and limited liability as having the same and thereby a mutual reinforcing purpose of stimulating entrepreneurship. Limited liability provides an incentive to invest and start new businesses. The possibility of allowing for secured credit, allows to attract additional finance to grow further, while allowing the shareholders to retain the full upside in the business without diluting their equity stake. However, just as limited liability and security rights share the same purpose of stimulating entrepreneurship, they also share the same problem of externalising business risks. Secured credit can therefore also be seen to exacerbate the risks related to limited liability. ${ }^{51}$

Despite the ferocity of the debate in the US, there were no legislative changes. Since the 1990s there has, however, been a consistent increase in the use of secured credit, ${ }^{52}$ with the result that the value is most often divided between different classes of secured creditors ${ }^{53}$ and nothing goes to the unsecured creditors. ${ }^{54}$ As will be seen, Germany and England did introduce some rules away from full priority.

50 Kripke 1985, p. 965, 966

51 See also Bebchuk and Fried, 1996, p. 49.

52 The ABI report, p. 12 provides the following data. Secured debt represented less than 45 percent of the debt of Moody's-rated firms filing for bankruptcy in 1991; by 2012, secured debt accounted for more than 70 percent of the debt of Moody's-rated bankruptcy filers. The ABI reports bases these data on Jenkins 2014.

53 The ABI Report provides at p. 217: "Although in 1978 the fulcrum security was almost always general unsecured claims, in more recent cycles, the fulcrum security was increasingly often at the senior creditor or subordinated senior creditor level."

54 The issue of full priority re-emerged in the American Bankruptcy Institute's Report from 2014 with Recommendations on the Reform of Chapter 11. One of the most novel and prominent recommendations in the $\mathrm{ABI}$ report is to allocate some value to the unsecured creditors if the 


\section{Productive versus unproductive secured credit}

The passionate pleas by Harris and Mooney and also by Schwarcz in favour of secured credit do bring to light that although not all secured credit might be beneficial for other creditors, the case can be made that if new money is provided against security and the bank is not acting as a pawn shop but is looking at the entire business, that security rights are likely to foster productive finance. Analysing the purpose for which secured finance is actually used is therefore merited. Looking at a balance sheet of a company attracting credit, one can easily distinguish between productive and non-productive secured finance.

\subsection{Credit facilitating economic growth and investments}

The most straightforward type of credit, and the credit that best fits the underlying justification of security rights, is credit that allows a company to invest in assets used for production or to provide working capital finance.

Assume the following balance sheet, of a company making a new product out of the garage. It has one working machine and some inventory, with a total value of $€ 250$ and no outstanding debt. The company is therefore fully equity financed.

\section{Balance sheet new company}

\section{ASSETS}

Machines

Inventory

\section{EQUITY \& LIABILITIES}

150

100
250
TOTAL 250

value breaks just above them'. The proposal, referred to as the redemption option value, has not (yet) received a follow up. See ABI Report, p. 207-224. 
If secured finance allowed the company to invest, the total value of assets of the company would increase, allowing the business to expand. At this phase, the company would usually also become able to attract not only bank finance, but also trade credit. Here the company could attract a possible €350 in secured finance and expand its asset side as well. After attracting secured credit (€350) as well as trade credit (€400), both the asset side and liability side will have increased.

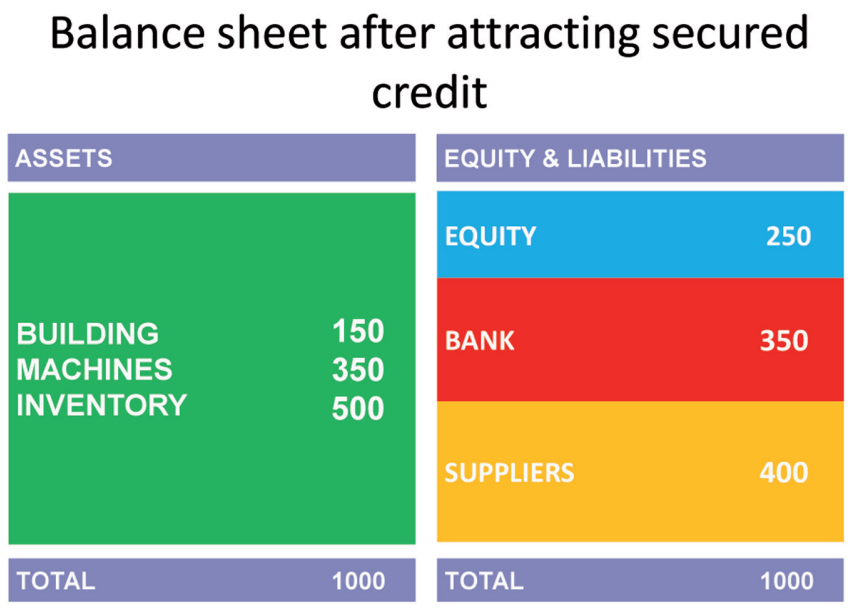

One of the problems of this optimistic version of secured finance is that banks do not really finance this initial phase of the company. Banks want to see both assets and steady cash flow. ${ }^{55}$ It will, therefore, be very difficult if not impossible, to get bank finance as a new business. ${ }^{56}$

The prime justification of secured credit is not limited to helping start-up companies grow into mature companies. To the extent that much more mature companies seek to expand their operations, and the bank provides credit to realise such expansion, the credit and the security rights securing it, form a good match with the underlying justification of security rights. Also, the bank can, in such cases, point out that if it had not been for the credit extended, there would

55 Murray, 2016.

56 The only realistic scenario is one in which the shareholder also provides security itself by means of a personal guarantee, in which case the bank is financing the sponsor and not solely the company. 
not be a machine, nor a building. It is also this kind of credit Harris and Mooney point to, when defending secured credit. ${ }^{57}$

\subsection{Second type of secured credit: Non-productive secured credit facilitating leverage}

There is also a form of credit, not intended to let the company make investments and grow, but rather to allow for distributions to shareholders and increasing the leverage of the company. In the balance sheet, equity is simply replaced by secured debt. There are two main versions hereof; Leveraged Buy Outs and Dividend Recapitalizations. Although the Dividend Recapitalizations are conceptually simpler, the widespread use thereof is a more recent phenomenon compared to LBO's.

\subsubsection{LBOs}

LBOs are a specific form of transfer of ownership of the company. The company to be acquired is usually referred to as the Target Company. A key feature of any LBO is that the acquisition of the Target Company by the new shareholder from the old shareholder is to a large extent financed by borrowing money, therefore by means of debt. The burden of repaying this debt and its related interest is however not borne at the level of the new shareholder, but at the level of the Target Company itself. Also, if the debt burden becomes too heavy, the Target Company will succumb and become insolvent.

There are four basic steps in an LBO transaction:

1. The new shareholder buys the shares in the Target Company from the old shareholder. The new shareholder is typically a Special Purpose Vehicle (SPV).

2. The Target Company borrows money from a bank providing security rights on its assets. Although the SPV can also be liable for the debt, the SPV will have no assets other than the shares in the Target Company. If the Target Company cannot make the payments to the bank, there is no real recourse against the SPV either since the shares held by the SPV will not represent any significant

57 See Harris and Mooney 1994, p. 2042, where they refer to purchase money financing and working capital loans. 
value. So economically the most relevant counterparty for the banks is the Target Company.

3. The money now available at the level of the Target Company flows upstream to the new shareholder, the SPV. This can be done either as a dividend payment or as a loan. In the case of a loan, the loan will usually be repaid not by making actual payments, but by means of set-off with future dividends.

4. The money now available at the level of the SPV as the new shareholder is used to pay the old shareholder for the purchase of the shares in the Target Company. The purchase price is for the larger part formed by the upstream liquidity. Part of the purchase for the shares will, however, still be provided by the new shareholder. ${ }^{58}$

The balance sheets of the Target Company change as follows. Prior to an LBO the company will have a reasonably solid solvency ratio.

\section{Balance sheet Target prior to LBO}

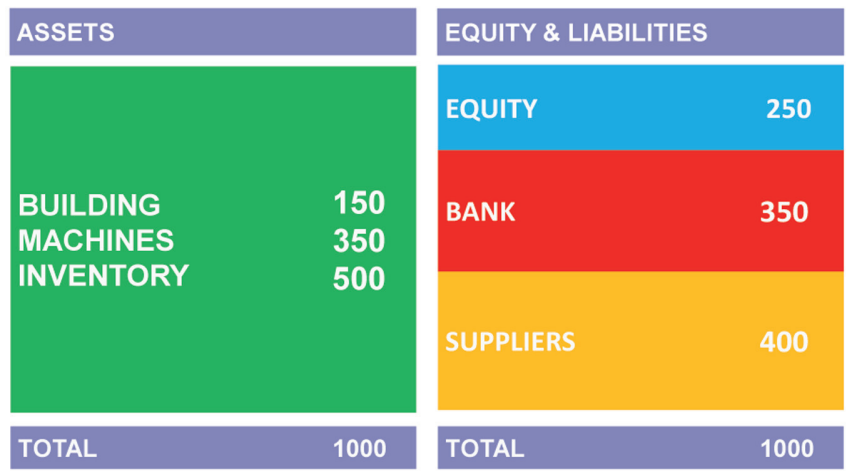

As part of the LBO transaction, the Target Company will borrow as much as possible. Momentarily the asset side therefore increases with cash.

58 See Ginsberg e.a. 2010, footnote 15 quoting different literature that places the relative part of debt finance at $70 \%$ or stating that LBO's are typically financed with 60 to 90 percent debt. 


\section{Balance sheet Target after attracting secured credit}

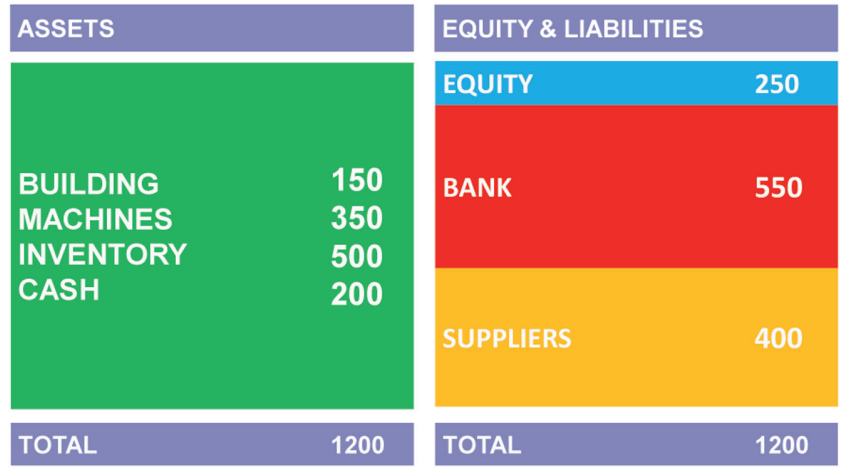

The cash will, however, be used to make a dividend payment to its new shareholder, which in turn will use it to pay the old shareholder. Cash and equity are thereby reduced with the same amount.

\section{Balance sheet Target after LBO}

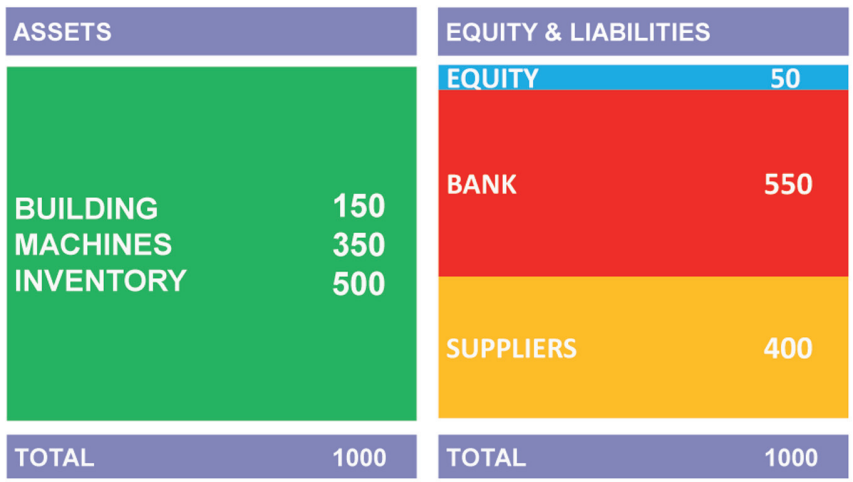


After completing the LBO, the Target Company will have taken on significantly more debt without any matching investments in its asset side. ${ }^{59}$ There is no investment made in the Target Company itself. The Target Company, once taken over, is burdened with debt, and the leverage of the Target Company has gone up.

A similar economic result can be reached by not making an upstream dividend payment, but an upstream loan from the Target Company to the SPV. In that case, the asset side will also have increased by the amount of the loan. If the Target Company cannot make the payments to the bank, then there is no real recourse against the SPV either. So the asset side of the balance sheet of the Target Company would list a claim against the SPV as an asset, but this asset will only represent value as long as the Target Company can meet its obligations to the bank.

There are some limitations in place, limiting the possibility to encumber the assets of the Target Company to facilitate its own acquisition. The most prominent restriction ${ }^{60}$ in place is the 2011 Directive on Alternative Investment Fund Managers (AIFMD). ${ }^{61}$ The industry's own assessment is that, "overall the Directive is

59 In case the up-streaming of the cash occurred by way of an upstream loan, the asset side would increase. The loan is problematic however, since it is a loan against the shareholder. Such loans are commonly not repaid, but instead reduced by means of set-off with future dividend payments. In case the target company would become insolvent, the company would have a claim against its parent which in case of being an SPV has no other assets than assets in the insolvent target company. Article 25 of the Second Company Law Directive provides that the Target Company 'shall include, among the liabilities in the balance sheet, a reserve, unavailable for distribution, of the amount of the aggregate financial assistance.' The Second Company Law Directive is, however, only applicable to public limited liability companies.

60 The directive contains a rule against what is referred to as 'asset stripping' in art. 30 AIFMD. Contrary to the term used, the key provision in this respect does not deal with selling of assets, but with dividend payments and other distributions to the shareholder. The provision is directed against the management of the fund, and not so much Target Company itself. The article provides that if a fund has taken over (acquired control) of a company, during two years the manager of the fund will not realise a capital distribution reducing the subscribed capital plus statutory reserves. The article is limited to distributions within two years. So upstream loans are not covered. See Barneveld 2013. A second rule (article 30 sub 2 under b AIFMD) provides that no distributions will be made that would exceed the amount of profits at the end of the last financial year plus any profits brought forward.

61 More effective limitations could be expected to be found in more traditional corporate law restrictions of financial assistance, which are directed directly at the Target Company. But these provisions also have shown a consistent retreat in different jurisdictions. The Second Company Law Directive and its limitations on financial assistance are to be applied to public limited liability companies only and not to closely held companies. See on the English rules on financial assistance Ferran 2014, Chapter 10. 
complex and represents a significant increase in regulatory disclosures and regulatory burden, but does not materially impede any private equity fund manager from continuing their business."62

A global multi-billion dollar market ${ }^{63}$ and industry has developed around LBOs, relying heavily on the use of security rights. Security rights in this context are not used for facilitating growth and are therefore at odds with the basic justification of their existence. The risk profile of trade creditors is changed without compensation, offering another example of 'uncompensated wealth transfer'.

Arguments can and have been made in favour of LBOs as well. The most prominent is that debt, much more than equity, can serve to discipline managers. This is commonly summarised by the expression, 'equity is a cushion, debt is a sword'. ${ }^{64}$ Jensen argues that attention should be paid to the positive effects of debt for shareholders due to its disciplining effect. He writes:

“For all the deeply felt anxiety about excessive borrowing, 'overleveraging' can be desirable and effective when it makes economic sense to break up a company, sell off parts of the business, and refocus its energies on a few core operations. Companies that assume so much debt they cannot meet the debt service payments out of operating cash flow force themselves to rethink their entire strategy and structure. Overleveraging creates the crisis atmosphere managers require to slash unsound investment programs, shrink overhead, and dispose of assets that are more valuable outside the company." ${ }^{65}$

This realignment of the incentives of management and shareholders by attracting debt, comes at the expense of an increase in externalisation of costs to unsecured creditors. ${ }^{66}$ To the extent that costs are externalised, this just means an additional

62 Private Equity Demystified, p. 94. This very much resembles the warning in 2007 from Ferran as to the limitations in art. 23 of the Second Company Law Directive. She writes (Ferran 2007, p. 32): "This article simply notes that no-one should be under any illusion that there already is robust protection in the form of Article 23, and that therefore there is no need for further regulatory intervention in this area." It should be understood that the AIFMD did not deliver such further regulatory intervention.

63 The total number of private equity buy out deals in 2015 and 2016 amounted to over 3915 and 3986 worldwide with a total value of USD 423 billion and USD 319 billion respectively. See Ligterink e.a. 2017, p. 48, with references to Preqin Quarterly Private Equity Update 2016. The data in the report as to 2016 is limited to Q1-3. From the Preqin database the numbers over the full year have been retrieved.

64 See Stewart and Glassman 1988: "Equity is soft, debt hard. Equity is forgiving, debt insistent. Equity is a pillow, debt a sword."

65 Jensen 1989.

66 See on this effect Armour et al. (2017), p. 112: "In general, the more successful the various strategies described (..) are in aligning managers' interests with shareholders', the stronger will be managers' incentives to act in a way that may benefit shareholders at creditors' expense." 
bonus for shareholders. In his praise for LBOs and the use of high levels of debts, Jensen presumes professional creditors and does not include non-financial creditors, such as non-adjusting trade creditors. For the beneficial effects of 'debt as a sword' as presented by Jensen to have effect, there should be creditors who both have an interest and the capability of wielding such sword. If the professional creditor is fully secured, he has no interest in doing so. At the same time, diversified trade creditors lack the capability to do so.

\subsubsection{Dividend recapitalizations}

Dividend Recapitalizations form another way in which secured credit is used without facilitating new investments in the company.

The receipt of dividends is an important way in which shareholders benefit from their investment. Although there might be equity in the company, the company can never distribute equity itself to its shareholders. The company will typically make a dividend distribution in cash, which will in turn reduce the existing equity. In order to be able to do so, the company needs cash. If the company has positive equity but no cash, it can attract a loan to acquire cash and use the cash to make a dividend payment. This is in essence what a dividend recapitalisation amounts to. The company borrows money in order to make a dividend payment to its shareholders. Depending on the company and the lender, the company can either borrow on a secured or an unsecured basis. When banks lend money in order to finance a dividend recapitalisation, they normally do so on a secured basis.

The steps of a dividend recapitalisation are straightforward. However, it is beneficial to outline these steps by means of a balance sheet. This helps to clarify why the term dividend recapitalisation, notwithstanding its widespread use, is itself misleading.

A company finds itself with positive equity and room to attract more finance, but without any cash to be able to make a dividend distribution. 


\section{Balance sheet prior to dividend} recapitalization

\begin{tabular}{|c|c|c|c|}
\hline \multicolumn{2}{|l|}{ ASSETS } & \multicolumn{2}{|c|}{ EQUITY \& LIABILITIES } \\
\hline \multirow{5}{*}{$\begin{array}{l}\text { BUILDING } \\
\text { MACHINES } \\
\text { INVENTORY }\end{array}$} & & EQUITY & 250 \\
\hline & 150 & \multirow[t]{3}{*}{ BANK } & \multirow[t]{2}{*}{350} \\
\hline & 350 & & \\
\hline & 500 & & \\
\hline & & SUPPLIERS & 400 \\
\hline TOTAL & 1000 & TOTAL & 1000 \\
\hline
\end{tabular}

If its shareholders and management believe that there is no real need for a solvency ratio of $25 \%$ and equity of $€ 250$, it could look for ways of making a distribution to shareholders. The first step is for the company to borrow money. The bank or another credit provider lends money, for example €200. This first ends up at the asset side as cash. The balance sheet total increases temporarily.

\section{Balance sheet after attracting secured credit}

\begin{tabular}{lrlr}
\hline ASSETS & & EQUITY \& LIABILITIES \\
& & EQUITY & 250 \\
BUILDING & 150 & BANK & \\
MACHINES & 350 & & 550 \\
INVENTORY & 500 & & \\
CASH & 200 & & \\
& & SUPPLIERS & 400 \\
& & & \\
\hline TOTAL & 1200 & TOTAL & 1200 \\
\hline
\end{tabular}

But the goal here was not to use the cash to invest and buy assets or make other capital expenditures. The goal was to use the money to make a dividend payment 
to the shareholder, here equal to the $€ 200$. So the money is used to make a dividend payment, thereby reducing both the asset side and the equity in the company. The resulting balance sheet looks like this:

\section{Balance sheet after dividend recapitalization}

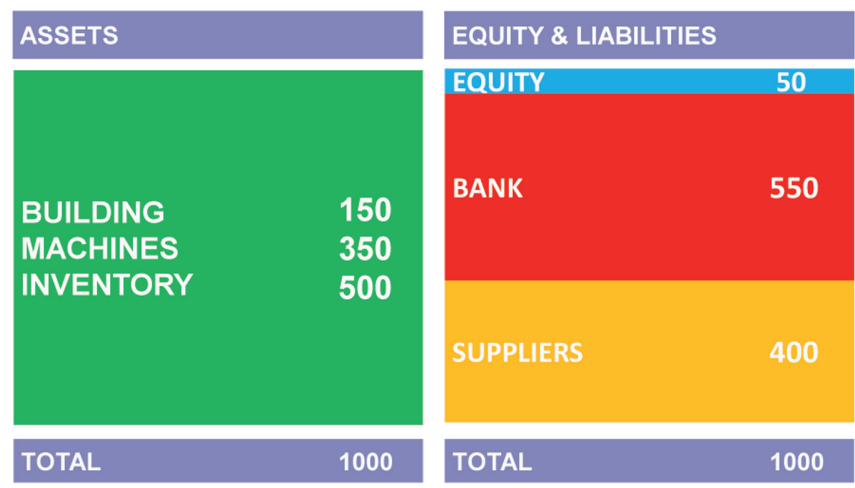

The term dividend recapitalisation is itself a contradiction in terms, at least to the extent that one uses the word capital to refer to the stake of the shareholder. What actually happens, is a dividend de-capitalisation. The amount of capital in a company is reduced by the amount of the dividend.

A dividend recapitalisation for shareholders is attractive for several reasons. Shareholders keep the full upward potential of the company but reduce their risk. At the same time, they receive cash which they can use for other purposes. The dividend does not match or relate directly to operational results. Instead, it simply reflects how much the company could borrow, which is indirectly determined by the future cash flows. ${ }^{67}$ Although attractive for shareholders, again costs are being externalised. The dividend recapitalisation increases the risks for unsecured creditors without any increase in interest payments to them.

Dividend recapitalisations are increasingly seen as an alternative exit strategy for private equity after a buy-out. The preferred exit strategy will still be to sell the Target Company, either through an IPO or to another investor. ${ }^{68}$ However, if

67 Gilligan and Wright 2014, p. 87.

68 See on the interconnectedness of the popularity of dividend recaps and the lack of other exit strategy end 2012, Philips and Hope, 2012: "Private equity firms remain focused on generating liquidity for limited partners that have seen relatively few liquidity events since the beginning of the 
the company cannot readily be sold, taking out equity can be seen as an alternative means of providing a partial exit. Dividend recapitalisations became increasingly popular in the beginning of 2000 but came to a stop with the crisis in 2008. They are now gaining popularity again. ${ }^{69}$

In case of LBOs and dividend recapitalisation, there is a clear, direct relationship between lending money and making payments to shareholders. The company borrows money for the sole purpose of paying out money to its shareholders. The effects of secured credit on facilitating leverage are not limited to such clear transactions where 'debt-in', matches 'equity-out' exactly. The process will normally be more diffuse, where the company has attracted secured debt and will later make dividend payments or conduct a share repurchase. This slightly more diffuse process also shows the same tendency, where money as credit is sought less and less for the purposes of investment, but instead to make pay-outs to shareholders. ${ }^{70}$

\subsection{Macroeconomic counterproductive high debt levels}

LBOs and dividend recapitalisations provide two examples of unproductive credit. The analysis was at the level of the company itself. One can also analyse the effects of lending at a macro-economic level. Here a similar pattern can be discerned as at the micro-economic level. A distinction can be made between productive credit and unproductive credit. In an immature economy, with low debt levels, providing additional credit increases growth. At low levels, finance is not simply a by-product of the development process, but actually an engine propelling growth, ${ }^{71}$ very much in line with the 'oil of the economy' argument. At

financial crisis. Both IPO markets and M\&A markets remain relatively stagnant in the current, uncertain economic environment. According to Standard \& Poor's, there have been only 14 IPOs of PE-backed companies thus far in 2012, and 29 sponsor-to-sponsor M\&A transactions. On the other hand, there have been 44 dividend recap deals through which the financial sponsors have recouped approximately two-thirds of their original capital commitment to the business, on average."

69 See http://www.leveragedloan.com/category/dividend/ with different postings on the volumes in the US. See a.o. Private Equity shops tap leveraged loans for hefty dividends, January 23, 2017.

70 See specifically on share repurchases, Lahart, 2016. He writes: "U.S. companies went on a borrowing binge in recent years. Nonfinancial corporations owed $\$ 8$ trillion in debt in last year's third quarter, according to the Federal Reserve, up from $\$ 6.6$ trillion three years earlier. (..) The negative: Rather than investing the funds they raised back into their businesses, companies in many cases bought back stock instead."

71 See Cecchetti and Kharroubi, 2012, p.1. See for a plea for a step away from full priority on the basis hereof Jonkers 2016. 
a certain level, the opposite happens. Too much credit can have a negative impact on growth. ${ }^{72}$ Cecchetti and Kharroubi address this point:

“(..) as is the case with many things in life, with finance you can have too much of a good thing. That is, at low levels, a larger financial system goes hand in hand with higher productivity growth. But there comes a point - one which many advanced economies passed long ago - where more banking and more credit are associated with lower growth.”

The IMF has also warned against the risks of high debt levels and is calling for a general deleveraging. ${ }^{73}$

\section{Beneficial effects of partial priority}

Proponents of full priority have tried to steer the debate away from abstract academic economic models to the actual use of secured credit in practice. While the outcome of the theoretical debate might have been left undecided, ${ }^{74}$ it is most notably the actual scope and use of secured credit that leads to the conclusion that allowing full priority is undesirable and a recalibration of the field of secured credit is needed. Secured credit is increasingly used to finance highly leveraged companies, as part of LBOs and to pay dividends in the form of a dividend recapitalisation, or more generally to facilitate leverage for its own sake (see above $\S 4$.2). In addition, a practice has emerged of financing with trade credit. These trade creditors can be viewed as adjustable creditors rather than nonadjusting creditors since they are not in the position to charge any interest at all (see above $\S 2.3$ ). Furthermore, there has been a sprawl of secured credit in the capital structure of companies resulting in empty estates (see e.g. above $\S 3.3$ as to the sprawl of secured credit in the US).

This section discusses how partial priority is a solution to these three developments. It discusses how partial priority will prevent empty estates ( $§ 5.1$ ), protect creditors in specific insolvency cases and also at a more general level (§ 5.2), and allow suppliers to specialise in what they do best (§ 5.3). It will also discuss a problematic development not yet introduced, namely how partial prior-

72 Arcand et al 2012. They write: "In particular, our results show that the marginal effect of financial depth on output growth becomes negative when credit to the private sector reaches 80 $100 \%$ of GDP."

73 See IMF Fiscal Monitor, 2016, p. 1, with its plea to deleverage the economy. "High private debt not only increases the likelihood of a financial crisis but can also hamper growth even in its absence, as highly indebted borrowers eventually decrease their consumption and investment."

74 See for an overall assessment of the debate, Armour 1998, p. 2. 
ity will protect unsecured creditors against insolvency laws that are too reorganisation friendly and too efficient ( $§ 5.4$ ). Depending on which goal to pursue, the non priority part will need to be smaller or bigger and also the design of the rule will differ.

\subsection{Preventing empty estates}

Insolvency procedures in the form of liquidation mean the end of the company as a legal entity. There are costs involved, even if the insolvency practitioner does little more than to assess who is entitled to what. As a result of the sprawl of secured credit, it is increasingly the case that there is no money whatsoever left to cover the basic costs of the insolvency procedure, including the salary of the insolvency practitioner.

Secured creditors benefit from the existence of an insolvency procedure. It therefore becomes questionable why secured creditors would not share in the costs of the procedure. This is aptly put by Tabb, who argues that:

"Outside bankruptcy, the secured lender may have considerable difficulty capturing anything above liquidation value. If the bankruptcy process itself allows the recovery of more value, why should all of that bankruptcy-enabled excess go to the secured lender."75

It is also already for the simple reason of an increase in empty estates without funds to pay for the court appointed administrator, that the Dutch Insolvency Practitioners' Association ${ }^{76}$ keeps pushing for partial priority. ${ }^{77}$

German law provides for a modest carve-out. The current rule is a watered down version of a proposal in 1985 that secured creditors would have to give $25 \%$ of their proceeds to the estate. ${ }^{78}$ That proposal was met with strong opposition, mainly pointing to the risk of hampering the availability of credit. ${ }^{79}$ The proposal was not accepted but some of the argument found its way into the current rules of contribution in costs. A German insolvency administrator will generally receive

75 Tabb 2015, p. 5.

76 See Insolad, 2012.

77 In the Netherlands a steady line of Supreme Court cases over the last 25 years has consistently improved the position of banks. A proposal for a carve out regime formed part of previous legislative proposal for a completely new insolvency act. See Kortmann Committee 2007. The entire proposal was however withdrawn.

78 Kommission für Insolvenzrecht 1985, p. 295-298 and 345-348. See also Mennens 2013.

79 See Drukarczyk 1987, p. 214-215. 
$9 \%$ of the proceeds of assets encumbered with a non-possessory security right as compensation for costs. ${ }^{80}$

The basic costs of an insolvency procedure should be covered by the participants to the procedure. This already warrants a rule that priority should not be $100 \%$, but that the secured creditor should bear some of the costs. A relatively low percentage of around 5-10\% would address the problem that there are often insufficient funds to pay the administrator. For the purpose of preventing empty estates, a simple carve-out rule could suffice and a more complicated fixed fraction partial priority rule would not be necessary. However, if other policy goals were to be pursued, a partial priority percentage of 5-10\% would not be enough and also a simple carve-out would be an inadequate response.

\subsection{Creditor protection}

\subsection{1. in a specific case: recalibrating the division in insolvency}

Harris and Mooney have been the most vocal critics of the proposals based on efficiency in favour of reducing full priority. They write the following:

\footnotetext{
"Although the Efficiency Literature may provide insights into certain effects of secured credit, we have seen nothing there, or anywhere else that would justify a major shift in policy. Were it clear (or even reasonably plausible) that debtors were reducing their costs of credit by securing some creditors and imposing the costs on unwilling (or unwitting) third parties, adjustments might be warranted." ${ }^{11}$
}

Knowing there are non-adjusting or even worse, adjustable creditors, justifies the proposal that not all value would flow to professional secured creditors in the case of insolvency. The freedom of contract and freedom of property arguments cannot justify parties contracting to the detriment of third parties when it is clear that these third parties are not in the position to adjust the terms of their contracts. Partial priority provides for a standard rule that the company and the secured creditor should also take into account the interests of third parties who are or are likely to be prejudiced by their contracting.

Since it will be difficult to distinguish between different types of credit in all given cases, a more general partial priority percentage is warranted, which would need to be set at a much higher level than just a cost sharing level of 5\%-10\%, for

80 Art. 171 InsO.

81 Harris and Mooney 1994, p. 2024 footnote 9. 
example $20-25 \%$. Such a percentage would allow for the payment of the insolvency practitioner's salary and provide some compensation in insolvency for the risks incurred by other creditors.

In England, a rule of partial priority has been implemented, but with limited scope and limited effect. ${ }^{82}$ The rule only applies to floating charges and it provides that the charge holder must make a certain percentage available for the satisfaction of unsecured debts, referred to as the prescribed part. The percentage is $50 \%$ of the first $£ 10,000$ and $20 \%$ of the excess above $£ 10,000$. The prescribed part is however capped at $€ 600,000 .^{83}$

For the purpose of increasing the pay-out in given cases, again a simple carve out rule could suffice and a more complicated fixed fraction partial priority rule would not be necessary. In the end, however, even a partial priority part of 20$25 \%$ is not likely to dramatically increase the pay out to ordinary unsecured creditors in a specific case, especially not if the prescribed part is capped. There is, however, a different way of protecting ordinary unsecured creditors.

\subsubsection{General protection against over-leveraging by means of partial priority}

Just as one should not judge the effect of security rights only by how they play out in insolvency procedures, one should also not limit the assessment of creditor protection offered by partial priority to the payout percentages in insolvency procedures alone. The most significant protection of unsecured creditors will not be in a specific insolvency procedure and an expected increase in pay out percentage. The real protection will be in protecting creditors against risks of financial over-leveraging, and thereby protecting viable companies entering into insolvency procedures in the first place. ${ }^{84}$

Leveraged finance poses risks, which are generally created by shareholders and secured lenders. Banks consistently defend themselves against criticisms of providing too much and unhealthy credit by arguing that they actually base their lending decision on many factors other than simply how much they expect to recover in case of insolvency (loss given default). During a legislative review preceding the Enterprise Act in the UK the British Bankers' Association said the following: "There is a perception ... that banks are effectively pawnbrokers, lending

82 The introduction of the prescribed part formed part of a larger reordering, most notably of the abolition of fiscal preference. See Goode 2011, p. 208-212.

83 Provided by section 176A of the Insolvency Act 1986 and the Insolvency Act 1986 (Prescribed Part) Order 2003.

84 See on this general effect, Jonkers 2016. 
only against security; or collateral. The truth is that banks principally lend against viability and collateral. Collateral is taken as a contingency if things do not work out as planned." 85 In the light of this standard rebuttal of criticism, the defence by a bank in a Dutch insolvency procedure is ironic. A Dutch trustee, Aukema, filed a claim on the basis of tort and ultra vires against ING Comfin, which had financed a leveraged buyout by means of secured debt. The trustee confronted ING with the argument that irresponsible risks had been created. ING defended itself by pointing out that it financed solely on the basis of assets and the expected loss given default and that it did not look into the larger transaction. ${ }^{86}$ The court denied the trustee's claims on appeal. The appellate court even went as far as to hold that there is no obligation for financiers of non-distressed companies to investigate whether the financing provided would create an unreasonable risk of insolvency of the company. ${ }^{87}$

Under US law, the responsibility of banks financing over-leveraged constructions is more commonly reviewed under transaction avoidance. ${ }^{88}$ One should ask the question of whether transaction avoidance is a suitable framework for dealing with this kind of overleveraged construction at all. At its core, transaction avoidance deals with preventing creditors from being prejudiced prior to insolvency, typically either by a transaction at an undervalue or a preference. In both cases (preferences and transactions at an undervalue), the direct counterparty can be said to gain an unfair advantage at the expense of the creditors in insolvency. In the case of secured credit facilitating leveraged finance, the problem is not so much a clear advantage of the bank at the expense of other creditors. The problem is the externalisation of risks by the shareholders, that is facilitated by secured credit provided by banks. Transaction avoidance is, in general, ill-equipped to deal with externalisation of business risks, even in extreme cases. Transaction avoidance commonly turns on the question of whether parties must have already foreseen the opening of insolvency procedures and prejudice caused to creditors. In case of over-leveraged finance, all parties (shareholders, management and banks) do genuinely hope for the best. There is, however, a strong element of opportunism in this genuine hope, since all parties involved have limited their downside risk to the largest extent possible.

The lack of specific controls on leveraged finance has also led to concerns within the European Central Bank. In May 2017 the ECB published its Guidance on

85 Taken from McCormack 2004, p. 10.

86 See District Court Utrecht, 12 December 2011, JOR 2011/382.

87 See Court of Appeals Arnhem-Leeuwarden, January 28, 2014, JOR 2014/316, case note Barneveld, under 4.9.

88 Ginsberg et al. 2011. See also Barneveld 2014, p. 113-152. 
Leveraged Transactions. ${ }^{89}$ The document contains instructions for significant credit institutions on implementing reporting and governance structures in their organisation so as to properly assess and control risks related to leveraged finance. In line with the supervisory role of the ECB, but still quite strikingly, the Guidance does not in any way seek to protect unsecured creditors against the risks of over-leveraging. It only seeks to prevent secured creditors from overstretching themselves in an era of very low interest rates, with the ensuing search for yield strategies and their exposure to leveraged finance.

The problem is that there is a prevalent practice of using secured credit causing the viability of companies to be unnecessarily put at risk, without proper compensation of other stakeholders. The law in general has great difficulties in recognising the shifting of risk, let alone addressing it. The result is that secured lending practice is shielding itself with the argument that secured lending should not be addressed, but rather the use of the proceeds, while continuing to extend credit at odds with the basic justification.

The best approach would be to internalise risks rather than using the threat of transaction avoidance. Under partial priority, banks and other secured lenders can then, and only then, justifiably refer to their lending decisions and argue that they calculated the risks, found them within reasonable boundaries and accepted part of those risks themselves. Not only would secured lenders have better incentives when granting loans, but also to intervene in a timely manner in the case of distress. A simple carve-out rule would not suffice for the purpose of forcing banks to internalise part of the risk. A more sophisticated fixed fraction partial priority rule would be necessary. There should also not be a set maximum of the prescribed part.

\subsection{Allow creditors to specialise in accordance with basic capitalism}

Partial priority seeks to recalibrate the scales in favour of the non-adjusting or adjustable creditor. The argument to do so, however, goes much further than simply preventing externalisation of risks. Improving the position of unsecured non-adjusting creditors while at the same time forcing financiers to assess and bear part of the insolvency risks, will reinforce the basic paradigm of a capitalist society with a free market economy. The most basic insight of Adam Smith was that that specialisation, and therefore trade, within and across a country's borders

89 See ECB Guidance on leveraged transactions, May 2017, p. 1-14. 
is critical to economic growth. The individual, and society, are held to be far better off if each and every person specialises in what he or she does best and simply buys the things that other people can make more cheaply. ${ }^{90}$

Fully secured credit, and its related current finance practices, clashes in two ways with the very basic premise of capitalism that everyone should focus on what he or she does best. Trade creditors are forced into doing things they should not be doing, while at the same time banks are not doing what they should be doing.

Suppliers that have to wait for long periods of up to half a year to receive payment on their invoices are manoeuvred into the position of trade creditor. ${ }^{91}$ The persons making candles, jeans, curtains and so on have to, by market force, deliver two kinds of products, namely the actual product, and credit. Instead of focussing solely on making the best product and competing with other suppliers on quality and price, these suppliers are forced to also assess the long-term credit risk of their buyers. Suppliers even have to compete with each other on how much credit they can extend and how much risk they are willing to take with their buyer. By and large these suppliers do not have these skills and they should also not be asked to fully develop them.

What is really baffling, is that the specialist in providing credit, the bank, is not doing what it is supposed to be doing. The bank should be assessing risks and possibly even be a guiding counsellor to the debtor. Under full priority the bank is not specialising in risk assessment, but in valuing assets. The real risk assessment of the company must now be made by the persons delivering jeans, shampoo and chocolate Easter bunnies. ${ }^{92}$ Partial priority forces banks to do what they should be doing and at the same time it will allow trade creditors to re-direct their efforts to doing what they do best. Here again, a simple carve-out rule would not suffice and a more sophisticated fixed fraction partial priority rule would be necessary if

90 See Baumol et al. 2007, p. 35.

91 Of course creditors supplying goods can sell under reservation of title and can thereby secure their claim for the purchase price. This will often not substantially change the problem addressed here. First of all, depending on the nature of the product, the risk will be significant that the value of this security is gone in full or at least to a high degree through consumption, production, deterioration or practical impossibility of tracing. These impediments to an effective protection by means of retention of title become all the more problematic the longer the payment terms are. Secondly, more aggressive finance practices have already shown the demand from strong buyers that the sellers waive their retention of title, which was also the case in the bankruptcy of V\&D. See for a court case combining both problems, namely the question of retention of title as well as the problems of invoking property rights, District Court Amsterdam, 8 november 2017, JOR 2018/52 (Trustees V\&D/Suppliers) with case note E.F. Verheul.

92 See on this effect of full priority, Jonkers 2016. 
the goal is to force banks, instead of trade creditors to assess the credit risk of the company.

\subsection{Provide checks and balances against too efficient and too reorganisation friendly insolvency laws}

One more argument in favour of partial priority needs to be added, since it addresses a threat to unsecured creditors from an unexpected corner. Insolvency law is undergoing rapid transformation at a European level. The European Union is now moving towards harmonisation of insolvency law by proposing a directive on Preventive Restructuring Framework. ${ }^{93}$ At a national level, many countries have also amended their insolvency acts, most notably regarding reorganisation procedures and in some cases also for pre-packs. Insolvency law is then no longer a repressive instrument, but is evolving into a restructuring tool, which no longer means the end of the business (pre-pack) or even the end of the legal entity (reorganisation plans).

The move towards more efficient and more reorganisation friendly insolvency laws is mainly implemented by taking out of the insolvency procedure those parties whose stake does not represent any value any more, neither in case of straight forward liquidation nor in case of reorganisation. It has long been recognized that shareholders should not have a blocking vote, since they are wiped out first. More recently, there is also a strong trend of silencing 'out of the money creditors', parties that also do not receive anything in case of liquidation, also not in case of a going concern sale. In the case of pre-packaged insolvency procedures, unsecured creditors are usually not involved. Their interests are by and large protected by disclosure requirements, explaining afterwards why the business was sold and how the highest price has been achieved and often also why there is not enough to make payments to unsecured creditors. ${ }^{94}$ In the case of a formal reorganisation procedure with a reorganisation plan, out of the money creditors are not allowed to block a reorganisation plan. ${ }^{95}$ If they vote against a

93 Proposal of 22 November 2016 for Directive of the European Parliament and of the Council on Preventive Restructuring Frameworks, Second Chance and Measures to Increase the Efficiency of Restructuring, Insolvency and Discharge Procedures and Amending Directive 2012/30/EU, COM (2016) 723. See in general on the proposed Directive, Tollenaar 2017.

94 Under English law, the administrator must provide the creditors with an explanation of why a pre-pack was conducted. See Statement of Insolvency Practice (SIP) 16.

95 See on the working of this proposed Directive, Eidenmüller 2017, who is critical among other reasons since the Directive does not distinguish between viable and non-viable businesses. He 
reorganisation plan but are considered out of the money, they can be crammed down by a court. ${ }^{96}$ In short, the economic value of a claim takes priority over the legal claim. Under the new paradigm, in case the claim does not represent value, the creditor should not be able to interfere with the insolvency procedures and in any way delay these.

Insolvency procedures can become too attractive. This is already evidenced by investors embarking upon loan-to-own strategies. The goal of a creditor is then not primarily to get repayment on its claim, but to acquire either the company or its assets. Investors can buy or extent secured debt and speculate on the insolvency of the borrower. The investor can then either acquire the assets by means of a credit bid or become the new owner of the company by means of a debt for equity swap. ${ }^{97}$ Under both scenario's, not only are the old equity holders are wiped out, but often also the unsecured creditors.

One can see how, from the perspective of unsecured creditors, these swift and efficient insolvency procedures become all the more problematic if all assets are secured. Increasingly there are no free assets whatsoever. In light of the other three developments of i) an increasing amount of secured debt with a broader scope, ii) where secured credit is used not to grow but to increase leverage, iii) while at the same time the unsecured creditors are unprofessional non-adjusting creditors being manoeuvred into the capital structure, this fourth development of allowing for a complete removal of such unsecured creditors from insolvency procedures becomes increasingly undesirable.

Insolvency law is creditor law, and should not easily be used by secured creditors against unsecured creditors. Providing for partial priority ensures simply and effectively that unsecured creditors will always be a stakeholder in insolvency. This is very much in line with the entire notion of insolvency being a collective procedure. Partial priority would also form a brake, or at least a clear financial hurdle, on using insolvency laws to acquire the company or its assets and leaving the unsecured creditors with nothing. Here a simple carve-out rule would suffice. A secured creditor could never simply wipe out unsecured cred-

fears the proposed Directive will 'attract non-viable firms like light attracts mosquitos'. It will also attract distressed debt investors embarking on a loan to own strategy.

96 Section 11 of the proposed Directive provides that Member States shall ensure that a restructuring plan which is not approved by each and every class of affected parties may be confirmed where the restructuring plan: (a) complies with the 'no-creditor worse off' test, (b) has been approved by at least one class of affected creditors, and (c) complies with the absolute priority rule. See on the working of these rules, Tollenaar 2017.

97 See in general on the strategies Athanas 2000. See specifically for the credit bid Belton 2006. 
itors. In case of a debt for equity swap, the unsecured creditors would always get $20 \%$ of the shares. ${ }^{98}$

\section{Conclusion}

Four large developments warrant revisiting the debate on full versus partial priority. Within bank finance, there is strong tendency not to finance start-ups or growing companies, but to finance fully grown companies with a steady cash flow and to facilitate dividend payments to shareholders by extending secured credit. Secured credit is then not used to make investments, but to facilitate shareholders to take out dividends and increase the leverage of the company. Secured credit is then used at odds with its most basic justification, namely to facilitate investments and growth. At the same time, the costs of increased insolvency risks are externalised more and more to trade creditors which are being targeted as a possible source of cheap finance. The scope and use of security also shows a steady increase, resulting frequently in empty estates. In addition, the position of unsecured creditors is worsened by a tendency of ever more flexible and reorganisation friendly insolvency law, allowing secured creditors not only to wipe out equity but also unsecured creditors.

Introducing partial priority will have several beneficial effects. It will address the problem of empty estates and can also be expected to provide a higher payout to unsecured creditors. Creditors will, however, also be protected at a more general level than by an increase in pay-outs. Banks will have to internalise the risks and so should make a true assessment of the risks involved. As a result, creditors will be protected against over-leveraged structures and against being confronted by insolvency procedures of otherwise viable businesses. Such a recalibration, forcing banks and other professional credit providers to assess the credit risks, is very much in line with basic capitalism where all parties specialise in what they do best. In the case of credit providers, that is assessing the credit risk of the company and not just the value of the collateral. Partial priority will also put a brake on the opportunistic use of insolvency procedures at the expense of unsecured creditors.

Debates on full versus partial priority have too easily been stifled by the mere suggestion that adjusting the valves of secured credit might lead to a decrease of the availability of credit and hurt the overall economy. In the light

98 In case of a credit bid on secured assets, this would mean that a bid would also have to be partially in cash still, up to the prescribed part. 
of the unprecedented global debt levels, which are hampering growth in themselves and pose significant risks, such a reduction can no longer in itself be a knock out argument. A distinction should be made between productive and unproductive credit. Secured credit provided to companies to simply leverage up for the benefit of shareholders without any investment, cannot be considered as productive credit.

\section{References}

ABI (American Bankruptcy Institute) Commission to study the reform of Chapter 11 (2015) Final Report and Recommendations. http://commission.abi.org/full-report. Accessed July 17 2017

Arcand JL, Berkes E and Panizza U (2012) Too much Finance. IMF Working Paper, 2012, WP/12/161

Armour J (2008) The Law and Economics Debate About Secured Lending: Lessons for European Lawmaking? Centre for Business Research, University Of Cambridge Working Paper 362: 131

Armour J (2000) Share Capital and Creditor Protection: Efficient Rules for a Modern Company Law. The Modern Law Review: 355-378

Armour J, Hertig G and Kanda H (2017) Transactions with creditors (Chapter 5). In R. Kraakman et al. (eds), The Anatomy of Corporate Law. A Comparative and Functional Approach, 3rd edition. Oxford University Press, Oxford, pp. 109-143

Athanas J (2000) Using Bankruptcy Law to Implement or Combat Hostile Takeovers of Targets in Chapter 11. The Business Lawyer Vol. 55: 593-623

Barneveld J (2013) De AIFM-richtlijn; geen verbod op asset stripping, maar een bestuursrechtelijke uitkeringsregel. WPNR 2013/6963

Barneveld J (2014) Financiering en vermogensonttrekking door aandeelhouders. Kluwer, Deventer

Baumol WJ, Litan E and Schramm CJ (2007) Good Capitalism, Bad Capitalism, and the Economics of Growth and Prosperity. Yale University Press, Yale

Bebchuk LA and Fried J (1996) The Uneasy Case for the Priority of Secured Claims in Bankruptcy. Harvard John M Olin Centre for Law, Economics and Business, Discussion Paper 166: 1-93

Bebchuk LA and Fried J (1997) The Uneasy Case for the Priority of Secured Claims in Bankruptcy: Further Thoughts and a Reply to Critics. Cornell Law Review 82: 1279-1348

Belton T (2006) The Venture Industries Credit Bid: A Template for Effective "Loan to Own" Acquisitions. Journal of Private Equity, Special Turnaround Management Issue, Spring: 115118

Business Insider, November 11, 2013. https://www.businessinsider.nl/douwe-egberts-brengt-le veranciers-in-ademnood-401768/. Accessed 17 July 2017

Brealey RA, Meyers SC and Allen F (2006) Principles of Corporate Finance. McGraw-Hill/Irwin

Cecchetti SG and Kharroubi E (2012) Reassessing the impact of finance on growth, BIS Working Papers, no 381

Drukarczyk J (1987) Kreditsicherheiten und Insolvenverfahren. ZIP 205

Drukarnczyck J (1991) Secured Debt, Bankruptcy, and the Creditors' Bargain Model. Int'l Rev. L. \& Econ. 11/203. 
Eidenmüller H (2017) Contracting for a European Insolvency Regime. European Business Organization Law: DOI 10.1007/s40804-017-0067-1

Fama EF (1978) The Effects of a Firm's Investment and Financing Decisions on the Welfare of Its Security Holders. The American Economic Review Vol. 68/3: 272-284

Ferran E (2007) Regulation of Private Equity - Backed Leveraged Buyout Activity in Europe. ECGI Law Working Paper No 84/007

Ferran E (2014) Principles of Corporate Finance Law. Oxford University Press, Oxford

Ginsberg JH, Burgess M, Czerwonka DR and Caldwel ZR (2011) Befuddlement betwixt two fulcrums: calibrating the scales of justice to ascertain fraudulent transfers in Leveraged Buyouts. American Bankruptcy Institute Law Review, Spring

Gilligan J and Wright M (2014, third edition) Private Equity Demystified. http://www.icaew.com/ en/technical/corporate-finance/financing-change/private-equity-demystified-an-explana tory-guide-160216. Accessed 17 July 2017

Goode R (2011) Principles of Corporate Insolvency Law. Sweet \& Maxwell, London

Hausemer P ea, (2015) Ex-Post Evaluation of Late Payment Directive, ENTR/172/PP/2012/FC-LOT 4

Harris SL and Mooney CWM (1994), A Property-Based theory of Security Interests: Taking Debtor's Choices Seriously. Faculty Scholarship, Paper 1290, 1994.

IMF (2016) Fiscal Monitor 2016. Debt: Use it Wisely.

Insolad, December 13, 2012, Voorstellen wijzigingen Faillissementswet

Jenkins M and Smith DC (2014), Creditor Conflict and the Efficiency of Corporate Reorganization, available at https://papers.ssrn.com/sol3/papers.cfm?abstract_id=2444700

Jensen M (1989) Eclipse of the Public Corporation. Harvard Business Review, also available at htt ps://papers.ssrn.com/sol3/papers.cfm?abstract_id=146149

Jonkers AL (2016) Het is tijd voor wat minder zekerheid. InsUpdates 2016. Kommission für Insolvenzrecht (1985) Erster Bericht, Verlag Kommunikationsforum, Köln

Kortmann Commissie (2007) Voorontwerp Insolventiewet, 21 november 2007. Kluwer, Deventer.

Kripke H (1985) Law and Economics: Measuring the Economic Efficiency of Commercial Law in a Vacuum of Fact. University of Pennsylvania Law Review 133/5: 929-985

Lahart, J (2016) Share Buybacks: The Bill Is Coming Due. Wall Street Journal, 28 February 2016.

Ligertink JE, Martin JK, Boot AWA, Cools K and Phalippou (2017), Private Equity in Nederland: een stakeholders-perspectief. Report commissioned by the Dutch parliament. https://www.rijk soverheid.nl/documenten/kamerstukken/2017/04/13/bijlage-private-equity-in-nederlandeen-stakeholder-perspectief

McCormack G (2004) Secured Credit under English and American Law. Cambridge University Press, Cambridge

Mennens A (2013) Over het verdelen van de taart in faillissement door middel van carve-out regelingen. Tijdschrift voor Insolventierecht 2013/38

Myers SC (2001) Capital Structure. Journal of Economic Perspectives 15/2: 81-102

Miller M (1988) The Modigliani-Miller Propositions After Thirty Years. Journal of Economic Perspectives 2/4: 99-120

Modigliani F and Miller M (1958) The Cost of Capital. Corporation Finance and the Theory of Investment. The American Economic Review, Vol 49: 639-655

Murray J (2016) Why do banks so NO to Business Startup Loans? https://www.thebalance.com/ why-do-banks-say-no-to-business-startup-loans-398025. Accessed 15 July 2017.

Philips J and Hope TJ (2012) Comeback of the Dividend Recap. https://www.stoutadvisory.com/ insights/article/comeback-dividend-recap. Accessed 17 July 2017 
Schwarcz SL (1997) The easy case for the priority of secured claims in bankruptcy. Duke Law Journal. Vol. 47/3: 425-489

Schwartz A (1981) Security and Bankruptcy Priorities: A Review of Current Theories. The Journal of Legal Studies Vol 10/1: 1-37

Schwartz A (1984) The Continuing Puzzle of Secured Debt. Faculty Scholarship Series. Paper 1120

Stewart G and Glassman DM (1988) The Motives and Methods of Corporate Restructuring (Part II). Journal of Applied Corporate Finance Vol. 1/1: 85-99

Stiglitz JE (1969) A Re-Examination of the Modigliani-Miller Theorem. The American Economic Review Vol. 59/5: 784-793

Tabb CJ (2015) The Bankruptcy Clause, the Fifth Amendment, and the limited rights of secured creditors in Bankruptcy. Illinois Law Review

Tollenaar NWA (2017) The European Commission's Proposal for a Directive on Preventive Restructuring Proceedings. Insolvency Intelligence 30/5: 65-81

Warren EA (1997) Making policy with imperfect information: The article 9 full priority debates. Cornell Law Review 6: 1373-1395 